\title{
The Partnership between the Public and Private Alternative or Supportive Iraq and Algeria as a Model for the Period (2004-2020)
}

\section{Ghassan Tareq Dhahir}

Assistant Professor, Banking and Financial Sciences Department, Al Muthanna University, Ministry of Higher Education \& Scientific, Iraq.

E-mail: Dr.Ghassan79@mu.edu.iq

\section{Wadhah Raheem Rahi}

Banking and Financial Sciences Department, Al Muthanna University, Ministry of Higher Education \& Scientific, Iraq.

E-mail: Wadhah_Raheem@mu.edu.iq

Received May 25, 2021; Accepted September 28, 2021

ISSN: $1735-188 X$

DOI: 10.14704/WEB/V18I2/WEB18379

\section{Abstract}

The study analysed the reality of partnership between the public and private sectors in Iraq and Algeria by highlighting the history of partnership in both countries and the legal legislation and the most important partnership contracts through existing investments. The study concluded that the reality of partnership in both alternatives is still weak and that most of the investments were not industrial. The task or the main sectors, but rather some public services administration projects, which may be covered by the state's public institutions, in addition to the fact that the total existing projects are very little compared to some Arab countries that have come a long way in this harm, such as the UAE, Qatar and even Saudi Arabia.

\section{Keywords}

Public Sector, Private Sector, Partnership, Quantitative Analysis, Basic Conditions.

\section{Introduction}

No doubt stimulating the local economy and preparing for the demands of economic development in most developed. The least developed countries fall on public spending in most countries, as the government undertakes the maintenance and maintenance of the economy. Rehabilitation of major projects such as energy, infrastructure, water projects, ports, airports, and many major problems would be no economic activities. However, the great developments and the impact of globalization and economic opening, which have 
made the world a small village, have contributed to the growth of the role of the private sector in light of the availability of vast and numerous business opportunities. In addition to government activities, the private sector has participated in the development and stimulation of growth in many capitalist countries such as South Korea, which companies manage most economic sectors, which call the Deshbol Group. Many countries have resorted to borrowing from private institutions; hence the great development witnessed by the dead countries. The private sector has played the main role in stimulating economic growth. Still, the question is very different in developing countries, especially in the research sample, because the government takes over the management of the economy in most of its articulations due to the weakness of the structure. And the ability of the private sector to manage large projects, for many reasons including lack of expertise and skills of the workforce, low fixed capital formation for the private sector, legal obstacles and restrictions and policies... etc. responsibility of the government to provide for the main requirements and even the private sector depends largely on government loans In Iraq. All sectors depend on the public budget For the Iraqi state, which in turn depends on oil revenues, as these revenues amount to about $98 \%$ of total dollar assets that Iraq gets. The issue is no different in Algeria because it is an oil country that mainly depends on oil. The two countries do not have the role of the private sector in the drawing of the characteristics. The local economy is only small proportions, and we will therefore present in this research the role of the private and public sectors in the economic partnership for the period 2004-2020.

\section{Research Literature}

Several studies have analyzed the partnership between the public and private sectors, in particular with the strengthening of links between countries due to trade openness and capital account liberalization, as well as the role of the private sector in the development of characteristics of the economies of developed countries, thus the International Monetary Fund published in its scientific series Economic Issues 2007, an article entitled The impact of public investment and the partnership between the public and private sectors, by researchers Bernardine Aktobe, Richard Hemming and Gerd Schwartz, the impact of public investment and the partnership mechanism between the two sectors. The researchers concluded that the partnership between the two sectors could be a good way to increase investment provided it is worded appropriately. The effect of this partnership, but it is not the magic in all cases, it is necessary to ensure that the partnership is correctly implemented and not willing to transfer expenditure items out of the budget and off-balance sheet debts. High priority should be given to strengthening the capacity of 
countries to identify and choose the appropriate partnership opportunities between the two sectors.

While a study titled (Development of public and private sector partnership: managerial aspects.) by researchers Živilè Tunčikienė, Adriana Grenčiková, Ilona Skačkauskienė research aimed to demonstrate the importance of partnership between the two sectors to stimulate growth and therefore its reflection on sustainable development, through the added value resulting from the activities of cooperative societies and institutions, as well as the increase in the capacity to cover basic needs, and this is accompanied by the development of administrative capacities of private sector institutions. The researchers used the analysis of the concept of partnership between the public and private sectors, explored the forms of this partnership, and analysed the management models in legal and administrative terms to assess the main partnership problems and seek solutions.

Also, a study by Argentino Pessoa entitled (Public-private partnerships in developing countries: prospects and drawbacks) aimed to analyze the role of the partnership between the two sectors in developing countries and its impact on economic and social reality by highlighting the creation of infrastructure, health and social services. However, this mechanism is not so simple due to the complex procurement methods and the influence of political conditions and economic issues, which makes it necessary for a legal and regulatory framework to ensure transparency and accountability. The credibility of this relationship between the different actors. The researcher concluded that this partnership lacked one or more of the required characteristics and efficient organization.

While researchers Jomo KS, Anis Chowdhury, Krishnan Sharma, Daniel Platz discussed the partnership with their research titled (Public-Private Partnerships and the 2030 Sustainable Development Plan: Fit for Purpose), the study aimed to cautiously focus on public-private partnerships (PPP) as a funding mechanism for infrastructure projects. Infrastructure through capacity building and knowledge sharing in financing economic development in Addis Ababa ensure the exchange between value and capital and create a mechanism to reduce potential financial risks. The issue of institutional capacity building and the evaluation of the partnership is essential for it to become an effective tool for the production of public services, such as infrastructure, and the need to find a common definition of the concept of partnership between sectors. public and private in international frameworks, international accounting standards and reporting. 
At the local level, the Private Sector Development Strategy 2013-2030 issued by the Council of Cabinet Advisers focused on the role of political factors in the decline of private sector participation in economic development, like instability, devastating wars and sanctions were reflected. Before 2003, and dependence on oil exports remove the role of the sector. Most of the national small and medium-sized enterprises, including nearly 33,000 projects operating in Iraq, were closed in the late 1990s due to competition from cheap imports and insecurity, as well as a significant increase annual population growth of $3 \%$, due to the decrease in the productive market shares of the private national sector.

1- The concept of partnership between the public and private sectors.

It is necessary to shed light on the concept of partnership and the specific mechanisms of that relationship to go into its midst when analyzing the reality of partnership for both selected countries. The partnership has been defined as (all the activities necessary to employ economic and social indicators in order to support the state's economy and raise the social level as well as on the other hand, it refers to the basic capital operations of these activities and annexed to them that would complete the implementation of investment projects to the fullest level (Yescombe, 2011).

The partnership is defined as all the activities that the government aspires to implement with the participation of the private sector, through contracting to include all the basic elements in completing this contract, such as the distribution of risks and the size of opportunities in the joint business that involves providing public services (Patrinos, 2009).

The World Bank also defined it as (a contract concluded by the government with the private sector to obtain a service with high specifications after determining the goals and level according to an agreed price for a specified period). (Rateb\& Anhar, 2016), while the Canadian Council defined it as a "cooperative project between the public and private sectors based on the experiences provided by each of the two sectors in order to meet a pre-determined general need and to play the best role by distributing the benefits and risks to the two parties" (Dwivedi, 2010).

2- Justifications for the partnership between the two sectors.

A - The inability of governments to achieve sustainable development on their own and with their limited capabilities.

B - The rapid technical and economic change provided the opportunity to reduce the cost of projects.

$\mathrm{T}$ - Increasing competitive pressures and declining growth rates. 
W - Limited financial, human and technological resources in the public sector due to the multiplicity of fields and projects that require implementation and the partnership works to reduce competition between these areas through the exchange of commitments between partners.

C- Decreasing the funding resources allocated for social development programs and the citizens' demands to improve the services provided by government institutions.

$\mathrm{H}$ - Increasing effectiveness and efficiency by relying on comparative advantage and division of labour, thus achieving higher returns for the money invested.

G- Expanding decision-making and setting economic policies that serve the public interest (Mustafa, 2016).

3- The elements for the success of the partnership between the public and private sectors The partnership's success as a contractual method between the public and private sectors depends on the availability of an appropriate environment to attract the internal and external private sector to contribute to the development of infrastructure, the provision of public services and the easing of restrictions on the public budget. Global experiences indicate that strengthening the partnership framework between the public and private sectors requires preconditions such as the availability of frameworks. Legal, institutional and organizational structures, setting up appropriate mechanisms for technical and financial support, as well as monitoring and managing the implications of risks and contents of partnership programs on the overall financial situation and levels of public debt, and finally providing strong political support, with a community culture supportive of the partnership. (Abu Bakr et. al., 2020).

The first requirement: Analyzing the role of partnership between the public and private sectors in Iraq.

After 2003, successive Iraqi governments sought to develop the private sector through the method of participation in achieving the requirements of economic development, in order to reduce pressure on the public sector in addition to implementing the directives of the International Monetary Fund, under the clause of raising the accumulated Iraqi debts. Iraq has the minimum operating government spending, in addition to supporting the private sector. The agencies affiliated with the United Nations country team funded a grant provided by the United Nations Development Group multi-donor trust fund to create a program for the development of the private sector in Iraq, specifically in 2009, with the participation of the government. Moreover, the private sector and other international development actors in Iraq in preparing for the development of the private sector development strategy and raising the percentage of its contribution to the gross domestic 
product, and the task of private sector participation has been included in the Iraqi constitution, as stipulated (the state guarantees the reform of the Iraqi economy following modern economic foundations in order to ensure full investment. its resources, diversification of its sources, and encouragement and development of the private sector) (Al-Waqa'i Al-Iraqiya, 2005).

Despite the enactment of laws and regulations and the endeavour to activate the mechanism of participation between the public and private sectors, it is characterized by the ambiguity of the role that the state plays in the national economy after 2003 , while the indicators tend towards strengthening market forces and giving more space to the private sector, but the government takes over most of the economic issues, as it interferes in many joints of economic and social life, which requires shedding light on this partnership greatly and defining its future paths and ways to enhance its role in economic growth (Bakhit \& Muhammad, 2015).

In order to get acquainted with the Iraqi business environment, since 2004 the World Bank has issued a Doing Business report, as Iraq was included in this report in 2007, which includes 189 economies, as the report provides a detailed analysis of the costs, requirements and procedures to which any type is subject. A certain number of private companies in all countries do justice on their basis.

Accordingly, Iraq was classified among the lowest ranks. However, since 2014, the Iraqi indicators began to give a kind of reassurance, and the indicators can be summarized according to the international report as follows:

1- Iraq advanced from 176th to 169th on the Starting a Business Index, thanks to simplifying the required procedures, which led to a significant shortening of the time required for registration from 77 days in 2012 to only 29 days in 2013.

2- The number of procedures required to obtain building permits decreased from 13 to 10 , which led to a decrease in the time required to obtain them. Iraq's ranking rose from 187 to 139 on this indicator.

3- Iraq's ranking also improved on other indicators. In terms of electricity delivery, Iraq's ranking improved from 46 to 39, but the number of procedures did not change. However, Iraq's ranking on obtaining credit declined from 174 in 2012 to 180 in 2013, while the strength of legal rights remained equal to 3 out of 10 . The main reason for this is that Iraqi banks - whether governmental or private - rarely grant loans and prefer to keep the money idle due to lack of confidence first and reflect indicators of the deteriorating political situation in Iraq. 
4-Iraq ranked worst in protecting investors, trading across borders, enforcing contracts and resolving insolvency. The Doing Business 2014 report indicates that importing or exporting goods took more than 80 days, and procedures for implementing contracts required 520 days. Iraq had no context to deal with bankrupt companies. (Private Sector Development Strategy, 2014-2030).

\section{Indicators of the Partnership Style in Iraq}

\section{1- Legal Legislation}

In the early years of changing the political system, the partnership was not clear-cut, as the role of the private sector in stimulating economic growth was indicated, in line with the decisions of the International Monetary Fund and harmony with economic openness. However, the deadly bureaucracy prevented the implementation of private projects. It contributed largely to economic development and the cases of financial and administrative corruption that Iraq suffered decades ago, which became widespread during the period of research. In 2019 Iraq witnessed the emergence of the birth of the Partnership Law. The first of Article 61, and the provisions of Clause Three, Article 73 of the Iraqi constitution, in the legislation of the Partnership Law between the public and private sectors, and the most important of what is stated in it:

A- Ensure that competition and transparency are achieved in concluding contracts.

B - Stimulating economic growth and encouraging the private sector in financing projects to raise performance efficiency.

C- Participation in the construction of infrastructure, public and productive facilities and services, or private sector projects.

D- Taking risks between the public and private sectors.

$\mathrm{C}$ - Safe recovery of costs and fair compensation for the private sector.

$\mathrm{H}$ - Linking all powers to the Council exclusively in determining what is appropriate (Inter-Sectoral Partnership Law, 2019).

\section{2- The Reality of the Partnership between the Public and Private Sectors in Iraq}

Private small and medium enterprises in Iraq occupy a prominent position, as a percentage of the total projects space, as the total of small enterprises, for example, industrial ones, amounted to about $(11,131)$ industrial projects in 2010 , and the number of workers reached $(36,898)$, or $(16 \%)$ of the total number of workers in The industrial sector in Iraq, despite the importance of private projects, but it faced many obstacles that prevented its progress or development, including weak government support, which was reflected in the 
quality of production and the increase in production capacity as well as the failure to provide the necessary protection for this sector and its products from foreign competition. (Saadoun, 2012).

After 2003, most Iraqi companies were subjected to looting and sabotage, which led to their complete or partial stoppage. It was not possible to qualify these companies for many reasons, the most important of which was the failure to allocate sufficient financial resources for this purpose, and that what was allocated for the rehabilitation and operation of these companies only met a limited number From companies, that is why most ministries, such as the Ministry of Industry and Minerals, have turned to search for other sources to operate their laboratories. In mid-2004, a commission was formed to study the privatization of this sector. The committee prepared an information base on public sector companies and prepared a draft law for the Privatization Authority. However, a decision issued cancelled this body in April 2005 without mentioning the reasons for this procedure, but the Council of Ministers is in its session. 29-8-2005 He re-examined the process of the cancelled Privatization Authority. Rather, a draft amendment legislation was prepared for the privatization of state-owned companies in various forms, one of which was the participation between the public and private sectors and since the legislation until now in the State Council is still in the study and drafting phase, and as a result of the delay in issuing this important law The Ministry of Industry and Minerals had no choice but to adopt Law 21 of 1997 that allows for the right to participate with the foreign private sector to implement works related to the objectives of partnership in Iraq, so the Ministry of Industry selected 13 companies and factories to present them as investment opportunities for the private sector to participate in their management and operation. For a period of 15 years, followed by another group of companies and laboratories, amounting to 36 companies, which offered these investment opportunities based on production participation. The investors have to assume responsibility for rehabilitation, management, operation and maintenance for a limited period. The public company obtains a share of the production until the end of the contract. The ownership of the rehabilitation equipment and the executed works reverts to the public company that has been shared with the private sector. Despite the difficult circumstances that Iraq is going through, there has been a remarkable demand To invest in these companies, as it was contracted to participate in seven factories, including five cement plants, one for electrical industries and another for petrochemical industries in Baiji, which was developed with the latest technological technologies and include a modern oil refinery, as well as production lines for many petrochemical materials exceeding forty products through ethylene and hydrocarbon lines. Annular. The Iraqi economy cannot rely on 
exporting crude oil only. However, the oil and gas industry must be developed and work on liquidating it to maximize the financial resources given the country's need to deal with economic problems. In this regard, other public sector projects are currently stalled or working with less from its available capacity for reasons related to its obsolescence, lack of capital to operate it, or otherwise, the private sector can be entered as a primary partner its re-operation. (Jaafar, 2012). For more information, the actual reality of partnership in Iraq can be identified through the following table:

Schedule 1 Largest projects in Iraq

- $\quad$ Largest projects

\begin{tabular}{|c|c|c|c|}
\hline PROJECT NAME & SECTOR & $\begin{array}{l}\text { FINANCIAL } \\
\text { CLOSURE } \\
\text { YEAR } \\
\end{array}$ & $\begin{array}{l}\text { INVESTMENT } \\
\text { (\$US MILLION) }\end{array}$ \\
\hline $\begin{array}{l}\text { Sulaymaniya Gas Power Station } \\
\text { SGPS }\end{array}$ & Electricity & 2008 & $\$ 1,000.00$ \\
\hline $\begin{array}{l}\text { Sulaymaniyah CCGT Plant } \\
\text { conversion and expansion }\end{array}$ & Electricity & 2016 & $\$ 500.00$ \\
\hline $\begin{array}{l}\text { Umm Qasr Container Terminal Berth } \\
8,10 \text { and } 11\end{array}$ & Ports & 2010 & $\$ 500.00$ \\
\hline Dohuk Power Station & Electricity & 2009 & $\$ 480.00$ \\
\hline Erbil Power Plant & Electricity & 2007 & $\$ 240.00$ \\
\hline $\begin{array}{l}\text { IQ Networks Turkey-Iraq broadband } \\
\text { cable }\end{array}$ & ICT & 2013 & $\$ 100.00$ \\
\hline Iraqna Telecom & ICT & 2003 & $\$ 100.00$ \\
\hline $\begin{array}{l}\text { IQ Networks broadband cable } \\
\text { extension }\end{array}$ & ICT & 2015 & $\$ 30.00$ \\
\hline $\begin{array}{l}\text { Sulaymaniyah CCGT Plant } \\
\text { conversion and expansion }\end{array}$ & Electricity & 2016 & $\$ 500.00$ \\
\hline $\begin{array}{l}\text { IQ Networks broadband cable } \\
\text { extension }\end{array}$ & ICT & 2015 & $\$ 30.00$ \\
\hline $\begin{array}{l}\text { IQ Networks } \\
\text { Turkey-Iraq } \\
\text { broadband cable }\end{array}$ & ICT & 2013 & $\$ 100.00$ \\
\hline $\begin{array}{l}\text { Umm Qasr Container Terminal Berth } \\
8,10 \text { and } 11\end{array}$ & Ports & 2010 & $\$ 500.00$ \\
\hline Dohuk Power Station & Electricity & 2009 & $\$ 480.00$ \\
\hline $\begin{array}{l}\text { Sulaymaniya Gas Power Station } \\
\text { SGPS }\end{array}$ & Electricity & 2008 & $\$ 1,000.00$ \\
\hline Erbil Power Plant & Electricity & 2007 & $\$ 240.00$ \\
\hline Iraqna Telecom & ICT & 2003 & $\$ 100.00$ \\
\hline
\end{tabular}

Source: PPP Knowledge Lab, on website https://pppknowledgelab.org/countries/iraq. 
Despite the large sums allocated and spent from the general budget, Iraqis have suffered for decades from poor electricity generation service. By referring to Table (1), we note that most of the investments were limited to preparing power stations for some cities, through contracts concluded by some provinces, with companies Local due to allowing local administrations to invest projects from the annual allocations to the governorates. Therefore, these investments are deficient as they depend on government expenditures and the absence of experienced foreign investments, so the results were not good, so Iraq still suffers from a power outage crisis.

The Requirement: Analysis of the Role of the Partnership between the Public and Private Sectors in Algeria

Algeria focused on the issue of partnership, specifically after independence. Because no official law was issued confirming this, the concept of partnership remained marginal until 1988, when Law 25-88 relating to directing national private economic investments liberalized the ceiling for private investment and allowed it to engage in all economic fields except for the strategic sectors. The issue of the partnership was strengthened by the issuance of Law 90-10 of 1990 related to cash and loans, as it is considered a cornerstone for the application of market economy principles and activating the role of the private sector in economic activity. It put an end to the state's hegemony over the joints of the economy, and according to which Algerian public or private enterprises were subject to the same treatment. (Draghi, 2014).

The total partnership projects amounted to about 26 projects from 1990 to 2015 , and the total value of actual investments amounted to $\$ 8,330$ million since 1990 . The partnership is distributed in various sectors between airport and energy projects, communications, gas extraction, and other projects. (Hamdouneh, 2017).

In 2006, Algeria witnessed establishing a project to manage public services for water and sanitation with the company SUEZ ENVIRONNEMENT. The second project is the management of the airport with the company Adam, followed by several projects after that, as Algeria in 2011 established a partnership with the company RATP Dev to manage Algeria's metro services and contracting with Accor., To manage hotel services, followed by 11 seawater desalination projects with the BOO company and the Algerian Energy Company (AEC), and during December 2017, a special charter was signed that frames the partnership with the participation of all partners in the National Economic and Social Contract for the growth of employers' organizations and the General Union of Algerian Workers. (Sridi, 2018). 
Algeria is among the top five African countries that have invested the most in PPP projects during the past 15 years, according to the 2016 report on economic development in Africa issued by the United Nations Conference on Trade and Development (UNCTAD), and one of the most prominent companies that have been contracted with for production and services In Algeria they are:

1- Lafarge company specialized in the production of building materials (cement, gravel, concrete and gypsum), as the Lafarge complex is an important model for a partnership contract for cement production as a gypsum unit for Bouira in partnership with the Algerian company Consider. The two projects provide jobs for approximately 2,600 employees.

2- The Constantine Water Management and Sanitation Company, The Siaco company, is the true example of the partnership concept in Algeria, as it is concerned with providing public services to purify water and distribute potable water continuously at the level of 12 municipalities in the wilaya of Constantine, according to a five-year concession contract between the two water companies of Constantine Algeria and the Marseille Company For French water, the contract was concluded in 2009 at a sum of 4.3 billion Algerian dinars. These two companies were assigned the task of managing, exploiting and disinfecting water, maintaining structures, reservoirs, water pumping stations and wells, as well as monitoring the quality and quality of distributed water, as well as running customer services and projects such as searching for water leaks and delivery works. Water through the distribution network, the period, the collection and the handling of customers' requests and their treatment, and about 2034 workers worked in this project until 2014. (Hamdouneh, 2017).

To get acquainted with the reality of the partnership between the public and private sectors in Algeria, we review the most important investment projects, according to the following table:

Schedule 2 Largest Projects in Algeria

\begin{tabular}{|l|l|l|l|}
\hline PROJECT NAME & SECTOR & $\begin{array}{l}\text { FINANCIAL } \\
\text { CLOSURE } \\
\text { YEAR }\end{array}$ & $\begin{array}{l}\text { INVESTMENT } \\
\text { (\$US MILLION) }\end{array}$ \\
\hline Medgaz Pipeline & Natural Gas & 2006 & $\$ 1,170.00$ \\
\hline $\begin{array}{l}\text { Shariket Kahraba Hadjret En Nouss } \\
\text { SpA }\end{array}$ & Electricity & 2006 & $\$ 1,150.00$ \\
\hline Sharikat Kahraba Skikda & Electricity & 2004 & $\$ 562.00$ \\
\hline Magtaa Desalination Plant & $\begin{array}{l}\text { Water and } \\
\text { sewerage }\end{array}$ & 2009 & $\$ 468.00$ \\
\hline
\end{tabular}




\begin{tabular}{|l|l|l|l|}
\hline $\begin{array}{l}\text { Consortium Algerien des } \\
\text { Telecommunications }\end{array}$ & ICT & 2005 & $\$ 465.00$ \\
\hline Kahrama SpA & Electricity & 2005 & $\$ 400.00$ \\
\hline Djezzy GSM & ICT & 2001 & $\$ 368.50$ \\
\hline Hassi R'mel Solar/CCNG Plant & Electricity & 2009 & $\$ 350.00$ \\
\hline Mostaganem Desalination Plant & $\begin{array}{l}\text { Water and } \\
\text { sewerage }\end{array}$ & 2008 & $\$ 250.00$ \\
\hline Oran plastic recycling facility & $\begin{array}{l}\text { Integrated } \\
\text { MSW }\end{array}$ & 2017 & $\$ 18.33$ \\
\hline Hassi Bounif Landfill & $\begin{array}{l}\text { Integrated } \\
\text { MSW }\end{array}$ & 2017 & $\$ 3.38$ \\
\hline Kabertene Wind Farm & Electricity & 2012 & $\$ 30.30$ \\
\hline $\begin{array}{l}\text { Societe des Eaux d' Assainissement } \\
\text { d'Alger (SEAAL) second } \\
\text { management contract }\end{array}$ & $\begin{array}{l}\text { Water and } \\
\text { sewerage }\end{array}$ & 2011 & $\$ 0.00$ \\
\hline Magtaa Desalination Plant & $\begin{array}{l}\text { Water and } \\
\text { sewerage }\end{array}$ & 2009 & $\$ 468.00$ \\
\hline Hassi R'mel Solar/CCNG Plant & Electricity & 2009 & $\$ 350.00$ \\
\hline Ports of Algiers & Ports & 2009 & $\$ 108.00$ \\
\hline Port of Djen Djen & Ports & 2009 & $\$ 0.00$ \\
\hline Mostaganem Desalination Plant & $\begin{array}{l}\text { Water and } \\
\text { sewerage }\end{array}$ & 2008 & $\$ 250.00$ \\
\hline Tenes Lilmiyah Desalination Plant & $\begin{array}{l}\text { Water and } \\
\text { sewerage }\end{array}$ & 2008 & $\$ 231.00$ \\
\hline
\end{tabular}

Source: PPP Knowledge Lab, on website https://pppknowledgelab.org/countries/algeria.

From the reality of the investments mentioned in Table (2), we note that most of the investments were limited to water desalination services, which is one of Algeria's dilemmas, similar to Iraq, which suffers from the crisis of power outages. Therefore both countries relied on partial investments despite the large allocations that It was spent. However, the problem appears all the time, and this is due to the lack of careful planning of the method of partnership, and the failure to allocate tasks, roles, opportunities and risks properly.

\section{Conclusions}

1- There are actual ingredients for the success of the partnership mechanism between the two sectors. However, it needs a real will for both sectors to complement one another and not a substitute, and the actual reality for both countries is the absence of actual frameworks for project distribution. State sovereignty even in light of contracting project 
management, and thus the opportunities and risks are not effectively distributed on the two sectors.

2- The weakness of the private sector operations in Iraq and Algeria led to their lack of the main components of project management, such as lack of expertise and lack of necessary funds, which ultimately highlights the dominance of the public sector over existing projects.

3- A significant decrease in the existing projects in the partnership between the two sectors and the limitation of these projects in their entirety to managing services.

4- The reflection of the security and political situations on the overall economic activities in both countries affected the decline of projects in light of their availability for investment.

5- The dominance of the oil sector as a leading sector has led to a decline in the relative importance of the private sector's participation in managing the wheel of the economy and achieving economic growth in both countries.

6- The absence of commercial courts specialized in commercial disputes weakens the private sector's confidence in the sector Government, which reduces the opportunities for private sector investment in both countries.

\section{References}

Ahmed, A.B., \& Tariq Abdel Qader, D. (2020). Frameworks for partnership between the public and private sectors in the Arab countries, Arab Monetary Fund.

Al-Waqi'a Iraqi Newspaper, The Iraqi Constitution, No. 4021, 2015.

Haidar, N.B., \& Abdul, W.M. (2015). Strengthening the partnership between the public and private sectors in Iraq as a development approach to contribute to achieving the Sustainable Development Goals 2015-2030.

Al-Saeed, D. (2014). Public-private partnership contracts as an effective mechanism for financing development, Journal of Human Sciences, Local, M, 2(41).

Gaurav, D. Public-Private Partnerships in Water Sector: Partnerships or Privatisation?. Manthan Adhyayan Kendra, Badwani, 2010.

Hamdouneh, M.A. (2017). The determinants of the partnership between the public and private sectors and their role in the growth of the Palestinian economy (from the point of view of the private sector in the Gaza Strip, the Islamic University, Gaza, 68-69.

Nabil, J. (2012). Public-Private Partnership in Iraq, Civil Dialogue, Issue No. 3702.

Jomo, K.S., Chowdhury, A., Sharma, K., \& Platz, D. (2016). Public-private partnerships and the 2030 Agenda for Sustainable Development: fit for purpose?.

Mustafa, H. Partnership between the public and private sectors to achieve the goals of economic development, Part 4, Issue 31.

Patrinos, H.A., Osorio, F.B., \& Guáqueta, J. (2009). The role and impact of public-private partnerships in education. World Bank Publications. 
Pessoa, A. (2006). Public-private sector partnerships in developing countries: Prospects and drawbacks (No. 228). Universidade do Porto, Faculdade de Economia do Porto.

Private Sector Development Strategy 2014-2030, Republic of Iraq, p.8 (1-114).

Public-Private Partnership Law. (2019). Republic of Iraq. p. (2-8).

Saadoun, Y. (2012). Small and medium industrial establishments, reality and prospects, Industrial Statistics Directorate.

Sridi, A. (2018). The reality of public-private partnership in Algeria, a case study of ETER Algerie. Cycma, University of May 1-112.

Tunčikienè, Ž., Grenčiková, A., \& Skačkauskienè, I. (2014). Development of public and private sector partnership: managerial aspects. Business: Theory and Practice, 15(1), 11-21.

Yescombe, E.R. (2011). Public-private partnerships: principles of policy and finance. Elsevier.

Dehghani, L., Basirian Jahromi, R., \& Ganjoo, M. (2011). Citations to highly-cited researchers by their co-authors and their self-citations: How these factors affect highly-cited researchers' h-index in Scopus. Webology, 8(2), 1-13. 